\title{
The Effect of Transport Stress on Plasma Levels of Catecholamines, Cortisol, Corticosteroid-Binding Globulin, Blood Cell Count, and Lymphocyte Proliferation in Pigs
}

\author{
By A.-M. Dalin, U. Magnusson, J. Häggendal, and L. Nyberg
}

Departments of Obstetrics and Gynaecology and Clinical Chemistry, Faculty of Veterinary Medicine, Swedish University of Agricultural Sciences, Uppsala and Department of Pharmacology, University of Göteborg, Sweden.

\begin{abstract}
Dalin, A.-M., U. Magnusson, J. Häggendal and L. Nyberg: The effect of transport stress on plasma levels of catecholamines, cortisol, corticosteroid-binding globulin, blood cell count and lymphocyte proliferation in pigs. Acta vet. scand. 1993, 34, 59-68. - The effect of transport stress on the plasma levels of catecholamines, cortisol, and corticosteroidbinding globulin were studied in 6 gilts. To assess the effect on immune status, white blood cells were also counted and the cell-mediated immunity was estimated. The adrenaline level increased significantly during transport, from a basal mean level of $0.03 \mathrm{ng} / \mathrm{ml}$ to a plateau level of 0.11 to $0.12 \mathrm{ng} / \mathrm{ml}$. The noradrenaline level fluctuated, but not constantly, during transport. The mean plasma cortisol level before loading was approximately $40 \mathrm{nmol} / \mathrm{l}$ and rose immediately after the start of transport to $70 \mathrm{nmol} / \mathrm{l}(\mathrm{p}<0.05)$ and to $87 \mathrm{nmol} / \mathrm{l}(\mathrm{p}<0.01)$ within 10 and $30 \mathrm{~min}$, respectively. After unloading the cortisol level rapidly decreased and a minimum level was seen $4 \mathrm{~h}$ after the transport, whereafter the diurnal rhythm was resumed. The plasma corticosteroid-binding globulin level increased nonsignificantly during the day of transport, from $25 \mathrm{nmol} / /$ to a level of $34 \mathrm{nmol} / /$, and it continued to increase until a plateau level was reached on the second day after transportation. The total white blood cell number increased significantly (from 13.7 to 15.5 $\mathrm{x} 10^{9} \mathrm{cells} / \mathrm{l}$ ), the number of lymphocytes decreased significantly (from 8.4 to $7.0 \times 10^{9}$ cells/l), and the number of polymorphonuclear neutrophils increased significantly (from 4.3 to $7.2 \times 10^{9}$ cells/l) during transport. No significant variation in the proliferation response was seen in the whole blood cell cultures. The main results were the significant signs of simultaneous activity of both the adrenal cortex and the adrenal medulla during transport.
\end{abstract}

gilts; transportation; WBC; lymphocyte-proliferation test.

\section{Introduction}

It is well known that transportation of pigs exposes the animals to stress. Transportation stress may be more or less severe, depending on a number of different factors, such as crowding, temperature, and duration. The active response to stress is considered to be mainly associated with activation of the adrenal medulla and the sympathetic nervous system (catecholamines (CA)), whereas passive response is thought to be related to stimulation of the pituitary-adreno-cortical system (see e.g. Henry \& Stephens 1977). Even if transportation stress is most often considered negative for the animals, it can 
have a positive effect on reproduction, such as inducing estrus in prepubertal gilts (Paredis 1961, Du Mesnil du Buisson \& Signoret 1962, Dalin et al. 1988) and in anestrous sows (Rojanasthien 1989).

Elevated blood levels of cortisol have been demonstrated after transport in pigs (Spencer et al. 1984, Dalin et al. 1988, Nyberg et al. 1988). In the latter 2 studies, the binding capacity of the corticosteroid-binding globulin (CBG) were also measured. The cortisol analyses normally used measure both bound and free cortisol. More than $90 \%$ of the cortisol is bound to $\mathrm{CBG}$, but it is the small unbound fraction that is considered to be the biologically active portion of the hormone. For review see Siiteri et al. 1982.

It has been suggested (Spencer et al. 1984) that cortisol is a better indicator of transportation stress than are other markers. High levels of CA in blood were found in pigs during intense experimental restraint stress, which is known to initiate the fight or flight reaction (Johansson et al. 1982). However, simultaneous measurements of the effect of transport on plasma catecholamines and cortisol levels do not seem to have been made in the pig.

Transport stress in cattle is thought to reduce the animals' resistance to the infectious complex that causes "shipping fever" (Hoerlein 1980). It may therefore be of interest to study the effect of transport stress on the immune system of the pig, because the immune system may be affected by cortisol as well as by CA (Fauci 1979, Crary et al. 1983, Landmann et al. 1984).

In the present study blood samples were taken before, during, and after a short transport for measurement of the plasma levels of cortisol, $\mathrm{CBG}$, and CA. The white blood cells were also counted and cell-mediated immunity was estimated. The animals' behavior was carefully followed.

\section{Materials and Methods}

\section{Animals}

Six crossbred (Swedish Landrace $\mathrm{x}$ Yorkshire $\mathrm{x}$ Hampshire) ovariectomized gilts not susceptible to stress, were used in the present study. The sire was $\mathrm{Hal}^{\mathrm{N}} \mathrm{Hal}^{\mathrm{N}}$. Their mean age was 10.8 months (range 9 to 13 months) and their mean weight $134 \mathrm{~kg}$ (range 116 to $149 \mathrm{~kg}$ ) at the start of the study. The ovariectomy was performed when the animals had passed puberty and at least 3 weeks before the start of the study. The gilts were kept in individual pens and restrictedly fed according to the Swedish stock standard. The animals were handled and used to close contact with the staff. For blood sampling, a silastic catheter was inserted into the jugular vein (Karlbom et al. 1982, Rodriguez \& Kunavongkrit 1983). The operations were performed under general anaesthesia (pentothal-sodium, 5\%).

\section{Transport}

The animals were transported 2 days after the surgery. The study was performed on 2 occasions with 3 gilts in each group. Before transportation, the animals were moved $40 \mathrm{~m}$ from the pens to the truck, where the gilts were kept in an area measuring $6.3 \mathrm{~m}^{2}$. The temperature during the transport was $10^{\circ} \mathrm{C}$ on the first occasion and $18^{\circ} \mathrm{C}$ on the second occasion. The transports started $5 \mathrm{~min}$ after loading at 9.00 and lasted for $1 \mathrm{~h}$. During transport the animals were observed and their behavior was recorded by the same observer (A.-M. Dalin). The transport was done on country roads under calm conditions at a speed of approximately $70 \mathrm{~km} / \mathrm{h}$. After the transport the animals were kept for an additional $5 \mathrm{~min}$ on the truck before unloading.

\section{Blood Sampling}

Blood samples were collected on the day after the catheter operation (d-1) at 9 a.m., 12 noon and 3 p.m. On the day of the transport (d 0), blood was sampled at 7.00 a.m., 8.00 a.m. and 9.00. a.m. 
Immediately after the last sample was taken the gilts were moved to the truck and samples were taken every $10 \mathrm{~min}$ from the start of the transport until $30 \mathrm{~min}$ after the transport. Blood sampling continued every $30 \mathrm{~min}$ for $1.5 \mathrm{~h}$ and thereafter every $\mathrm{h}$ for $5 \mathrm{~h}$. Blood samples were then taken every $3 \mathrm{rd} \mathrm{h}$ from 5 p.m. until 5 a.m. the following day. Thereafter, sampling continued 3 times a day ( 9 a.m., 12 noon and 3 p.m.) for 5 days ( from day +1 to day +5 ).

Blood (10 ml) for cortisol and CBG determinations was collected in heparinized tubes and centrifuged as soon as possible. The plasma was then stored at $-18^{\circ} \mathrm{C}$ until it was assayed. For the assay of CA, $5 \mathrm{ml}$ of blood was transferred to a tube containing $140 \mathrm{IU}$ of heparin and $100 \mu \mathrm{l}$ of a 0.4 $\mathrm{M}$ glutathion solution. The tubes were kept in ice-water and centrifuged at $+4^{\circ} \mathrm{C}$. The plasma was stored at $-70^{\circ} \mathrm{C}$ until it was assayed. Blood samples from frequent sampling during and after the transport were analyzed for CA. For blood cell counts and the lymphocyte proliferation test, tubes containing EDTA and heparin, respectively, were used.

\section{Hormone and Corticosteroid-Binding Globulin assays}

Plasma concentrations of cortisol were determined by direct radioimmunoassay as previously described and validated (Nyberg et al. 1988). The binding capacity of corticosteroid-binding globulin, CBG, was estimated as a 1-point assay and included the addition of cortisol to saturation according to Nyberg et al. (1988). The catecholamines (CA), adrenaline (A) and noradrenaline (NA) were measured by electrochemical detection after high performance liquid chromatography according to Keller et al. (1976) as modified by Hallman et al. (1978).

\section{Blood Cell Count}

The total number of white blood cells (WBC) was counted in a celloscope and differential
WBC counts were carried out using blood cell smears stained with Giemsa's and May Grünewald's solutions. The blood analyses were performed according to the standard procedures at the Department of Clinical Chemistry, Swedish University of Agricultural Sciences.

Blood samples for cell counts were collected at 9 a.m and 3 p.m. on day -1 , on the day of transport at 8 a.m., during transport, directly after transport, at 4 p.m. and at 11 p.m. (day 0). During the 2 days after transport samples were collected once daily at 9 a.m. (days +1 and +2 ).

\section{Lymphocyte Proliferation Test}

To estimate the cell-mediated immunity, a whole-blood lymphocyte proliferation test was performed according to Magnusson \& Fossum (1988). In brief, $100 \mathrm{ml}$ of heparinized blood diluted 1:10 in growth medium was cultured with or without (unstimulated cultures) $100 \mu$ l of growth medium, containing the T-cell mitogen Concanvalin A (Pharmacia, Uppsala, Sweden) at a concentration of $10 \mu \mathrm{g} / \mathrm{ml}$ for $3 \mathrm{~d}$ at $37^{\circ} \mathrm{C}$. The cell cultures were then pulsed with $\left({ }^{3} \mathrm{H}\right)$ thymidine for another $24 \mathrm{~h}$ before harvest. The proliferative response of the lymphocytes was expressed as mean counts per min (cpm) for replicates of 4 from the 2 types of cultures. Blood samples for the lymphocyte proliferation assay were collected using the same scheme as that for the blood cell counts, but the last sample was excluded for technical reasons.

\section{Statistical Analyses}

Statistical analyses of the data from the cortisol and CBG determinations were carried out using the analysis of variance procedure and the 2-sample analyses using the Statgraphics statistical package (STSC. Inc., Rockville, MD). Two-way interactions were tested and found to be nonsignificant. For the CA values analyses of variance, repeated measurements were used, 
followed by Fisher's protected lsd test (Statview SE + Graphics, Abachs Concept Inc., Berkely, CA, USA). The data from the WBC counts and lymphocyte proliferation tests were analyzed using the GLM procedure of the SAS Institute Inc. (1987). In this procedure, a statistical model including the effect of animal, occasion of sampling, and transport occasion was applied to the data. Results from the hormonal analysis are expressed as mean \pm SEM, and those from the WBC count and the lymphocyte proliferation test as least squares means $\pm \mathrm{SE}$.

\section{Results}

The animals were busy sniffing at the straw bedding and at each other immediately after loading. Small, short fights between the animals arose occasionally. During transport the animals seemed to be occupied keeping their balance (sawhorse position), and the periods of fighting were only brief and seen at variable intervals. Two out of 6 animals lay down during transport, the total time for both being $2 \mathrm{~min}$.

The mean \pm SEM level of $A$ in the 6 animals is shown in Fig. 1. The mean basal level of $A$

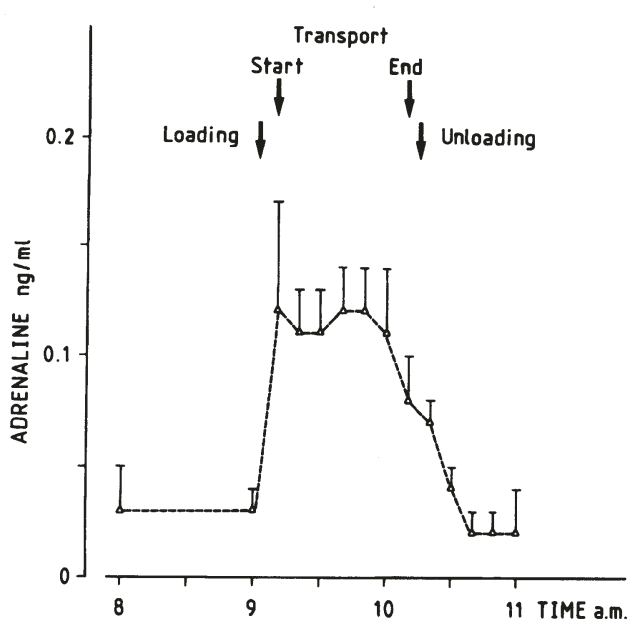

Figure 1. The mean \pm SEM plasma level of adrenaline in 6 gilts during transport.

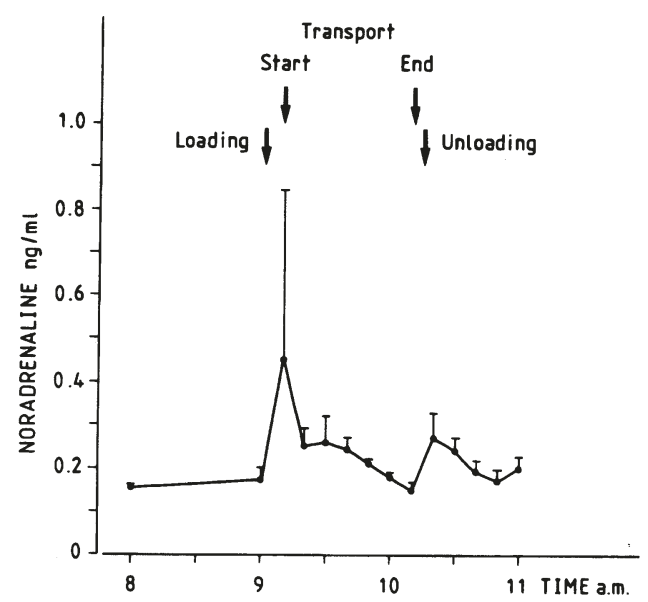

Figure 2. The mean \pm SEM plasma level of noradrenaline in 6 gilts during transport.

before the transport was $0.03 \mathrm{ng} / \mathrm{ml}$ and increased significantly $(\mathrm{p}<0.01)$ during the loading and transport to a plateau level of 0.11 to $0.12 \mathrm{ng} / \mathrm{ml}$. The basal level of $\mathrm{A}$ was seen again $30 \mathrm{~min}$ after the end of the transport. The NA level fluctuated within the animals and between the animals. The mean NA levels (Fig. 2) were significantly higher $(\mathrm{p}<0.05)$ only in the first sample

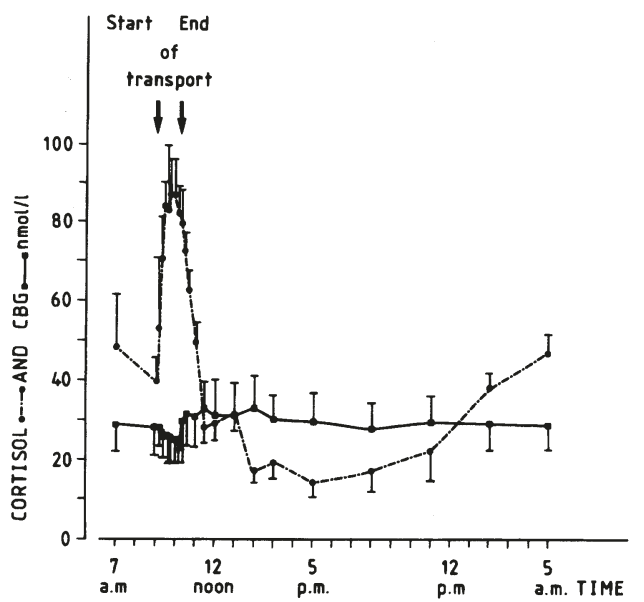

Figure 3. The mean \pm SEM plasma level of cortisol and binding capacity of corticosteroid-binding globulin $(\mathrm{CBG})$ in 6 gilts on the day of transport. 
taken after loading, compared with the levels before loading.

The mean \pm SEM plasma level of cortisol and CBG binding capacity for the 6 animals during the day of transport are shown in Fig. 3. There was an immediate increase in the cortisol level after the start of transport. The mean plasma cortisol level before loading was approximately $40 \mathrm{nmol} / \mathrm{l}$. Immediately after the start of transport the cortisol level increased significantly to $70 \mathrm{nmol} / 1,(\mathrm{p}<0.05)$; the highest lev$\mathrm{el}, 87 \mathrm{nmol} / \mathrm{l}(\mathrm{p}<0.01)$, was measured 30 min later. The plasma levels remained high during transport and decreased rapidly after unloading to a significantly lower mean level of about $50 \mathrm{nmol} / \mathrm{L}(\mathrm{p}<0.05)$, compared with the maximum level. This was observed $80 \mathrm{~min}$ after the end of transport. A minimum cortisol level of $17 \mathrm{nmol} / \mathrm{l}$ was found $4 \mathrm{~h}$ after transport. After that period, the changes in the plasma cortisol level returned to the diurnal rhythm. In Fig. 4 the daily levels ( 9 a.m. to 3 p.m.) of cortisol and CBG binding capacity are shown from $d-1$ to $d+5$ (day of transport $=d 0)$.

In the 6 animals, the mean plasma CBG binding capacity on the day of transport was 28 nmol/l before loading (at 9 a.m., Fig. 3). With-

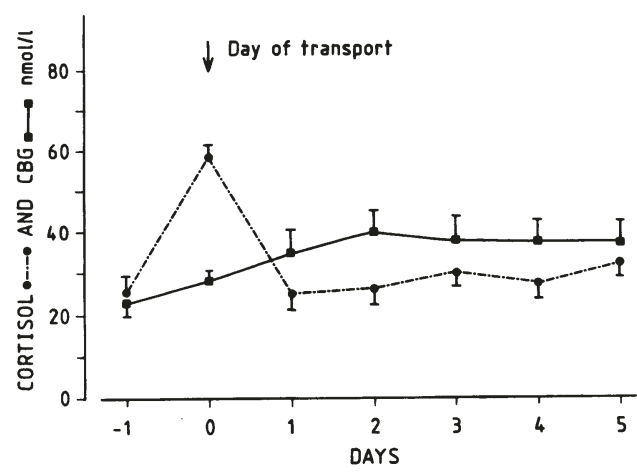

Figure 4. The mean \pm SEM daily level of cortisol and binding capacity of corticosteroid-binding globulin in 6 gilts during day -1 to day +5 (the day of transportation $=$ day 0 ). in 30 to 40 min after the start of transport, there was a decrease in the mean CBG binding level to $25 \mathrm{nmol} / 1$ and thereafter an increase to a maximum level of $34 \mathrm{nmol} / 14 \mathrm{~h}$ after transport; the changes were nonsignificant. After the day of transport, the mean binding capacity of $\mathrm{CBG}$ steadily increased until a plateau level was attained on the second day after transportation (Fig. 4).

The total mean number of WBC increased significantly $(\mathrm{p}<0.05)$ during transport, from 13.7 $\mathrm{x} 10^{9}$ cells $/ 1$ in the morning to $15.5 \times 10^{9}$ cells $/ 1$ immediately after transport. Moreover, the total number of WBC was lower $(\mathrm{p}<0.001)$ the second day after transport than on the day before the transport. The mean number of circulating lymphocytes decreased significantly ( $\mathrm{p}$ $<0.05$ ) from $8.4 \times 10^{9}$ cells $/ 1$ in the morning to $7.0 \times 10^{9}$ cells $/ 1$ immediately after transport (Fig. 5). Conversely, the mean number of polymorphonuclear neutrophils (PMN) increased significantly $(\mathrm{p}<0.001)$ from $4.3 \times 10^{9}$ cells/ 1 in the morning to $7.2 \times 10^{9}$ cells/l immediately after transport (Fig. 5). As with the total number of WBC, the number of PMN was lower $(p<0.05)$ 2 days after than the day before the transport.

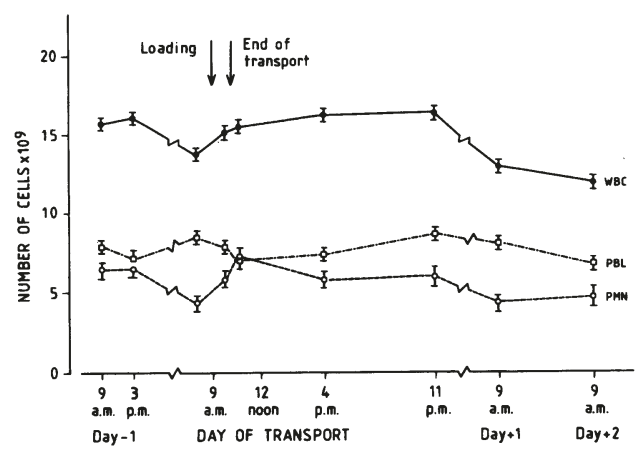

Figure 5. The mean total number (x 109/1) of white blood cells (WBC), peripheral blood lymphocytes (PBL) and polymorphnuclear neutrophils (PMN)from day -1 to day $+2($ the day of transport $=$ day 0$)$ 


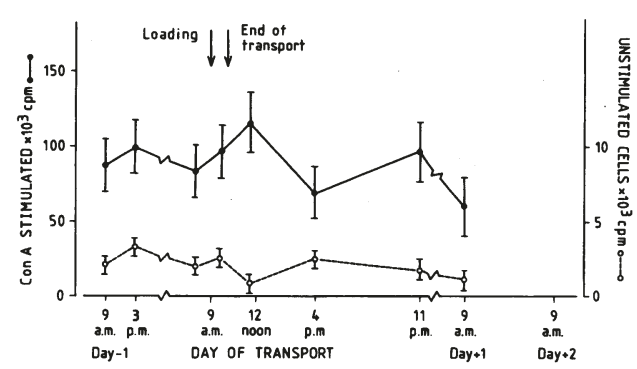

Figure 6. The proliferative response of the lymphocytes, Concanvalin A-stimulated and unstimulated cells, day -1 to day +2 (the day of transportation $=$ day 0 )

The proliferative response in the whole blood cultures, stimulated with Concanvalin A, did not show any significant variations throughout the study; the least squares means of the cpm values varied between 115,376 cpm and 60,101 cpm (Fig. 6). In the unstimulated whole blood cultures, the cpm value in the cultures of blood collected immediately after the transport (743 $\mathrm{cpm})$ was lower $(\mathrm{p}<0.01)$ than that in the cultures of blood collected during the transport $(2,541$ $\mathrm{cpm})$ and in the afternoon the same day $(2,449$ cpm).

\section{Discussion}

In the present study the plasma profiles of CA, cortisol and $\mathrm{CBG}$ were followed by frequent blood sampling in ovariectomized gilts during short-term stress induced by transport. Their behavior during the transport was also carefully followed and data on the WBC and the cellmediated immunity were obtained.

The animals were not "stress-susceptible" and they were used to close contact with the staff. A previous study (Dalin et al., unpublished) has shown that pigs easy adapt to blood sampling and do not show raised cortisol plasma level due to the frequent blood sampling. Futhermore, the animals were ovariectomized to avoid the influence of oestrous on cortisol (Becker et al. 1985a, Dalin et al. 1988). Therefore, the reactions in the animals during the transport study can be considered due to the transport itself. Futhermore, the degree of transport stress in this study ought to be considered mild (i.e., there was no overcrowding and the temperature was relatively low). During the transport, which lasted $1 \mathrm{~h}$, the pigs seemed to be occupied mainly by exploring the new environment and keeping their balance. This is in agreement with Lambooy (1988), who observed the behavior of pigs by video during a long-distance journey. Thus, most of the stress that the animals were exposed to in the present study seems to have originated from the new environment and the transport rather than from agression between them.

The A level found in the present study was significantly increased during almost the whole period of stress. A considerable amount of psychoendocrine research has discussed CA, particularly A, as an indicator of mental stress (Akerstedt et al. 1983). The increased levels of A found in the present study may therefore reflect mental stress during the transport.

Increased NA levels seem to be seen mainly during physical activity. Decreased muscle sympathetic activity has also been demonstrated during mental stress, followed by increased NA levels upon termination of the stressexposure (Akerstedt et al. 1983). The change in the NA level in the present study was small, except for brief periods in individual cases. This is in agreement with the only moderate muscle activity observed. The tendency to increases in the NA values after unloading at the end of the transport may be connected with increased muscle activity but also with the termination of the stress.

Even though the levels of $\mathrm{A}$ in the present study were low, compared with the levels seen at experimental, intense restraint stress, provoked by the myorelaxant succinylcholine and causing myocardiall cell necrosis (Johansson et al. 1982, Häggendal et al. 1988), the levels of $\mathrm{A}$ in the 
present study reached such high values that the A may cause physiological effects, such as increased levels of cyclic AMP in plasma. The NA levels were, however, probably without any marked effects (Hjemdahl et al. 1983). It should be observed that for technical reasons venous blood plasma was used for the CA measurements in the present study, even if arterial blood would have been more relevant (Hjemdahl et al. 1984).

In earlier studies on transport-induced stress, blood sampling for hormone assay was performed only before and after transport. In the present study, a rise in the plasma cortisol concentrations were found in connection with the transport, which is in agreement with earlier studies (Spencer et al. 1984, Becker et al. 1985b, Dalin et al. 1988, Nyberg et al. 1988). However, the present study clearly shows that the rise in the cortisol level occurred immediately after the start of the transport and that the maximum level of cortisol was reached during the transport, not after unloading, which has been reported by Becker et al. (1985b). After the transport the decrease in the cortisol level was rapid and the pigs returned to their diurnal rhythm $4 \mathrm{~h}$ later. In the present study, during transport the blood levels of both cortisol and A increased at the same time. This may indicate simultaneous release from both the adrenal cortex and the adrenal medulla.

Even if the stress in the present study can be regarded as mild and the effect on the CA and cortisol levels was brief, this type of stress has a positive effect on the reproduction in pigs, in that transport stress induces oestrus both in prepubertal gilts (Paredis 1961, Du Mesnil du Buisson \& Signoret 1962, Dalin et al. 1988) and in anestrous sows (Rojanasthien 1989). Shilling \& von Rechenberg (1973) and Barb et al. (1982) found that treatment with ACTH or glucocorticoids had an inhibitory effect on the ovarian activity and blocked the ovulation.
Therefore, the stimulatory effect of transport on reproduction found in prepubertal gilts and anestrous sows might not be due to a raised cortisol level but to a raised level of CA (Dalin et al. 1988). This is in agreement with studies that suggest that adrenergic nerves participate in the control of ovarian function. For reviews see Burden (1985), and Spicer (1986).

The mean CBG binding capacity level did not change markedly during exposure to transport stress, which indicates that the increase in the cortisol level observed during the stress was an increase in the free fraction of cortisol. Furthermore, there was a steady increase up to the 2 nd day after transport. To compare, in an earlier study by Dalin et al. (1988), the binding capacity of CBG did not change during the day of transport but a significant decrease was seen the day after. However, in that study the animals were catheterized on the same day as the transport, and recent results (Dalin et al. unpublished) show that the operation itself induces a significant decrease in the CBG binding capacity the day after the operation. In the present study, the effect of the operation on the CBG binding capacity can be disregarded because the CBG is back to the normal level $2 \mathrm{~d}$ after surgery (Dalin et al. unpublished).

The significant changes in the total number of WBC in the present study were the result of alterations in the number of PMN cells. In an earlier study, diurnal changes in circulating leukocytes in the pig were observed (Magnusson \& Dalin 1992). However, these diurnal changes were not dramatic, particularly not from morning to noon, and thus did not correspond to the sudden and highly significant changes in the number of circulating PMN cells or lymphocytes at transportation in the present study. Thus, the rapid increase in circulating PMN cells during transport was probably an effect of the release of cortisol into the circulation (Fauci 1979). Alternatively, the neutrophilia may have been 
due to the combination of high cortisol levels and elevated CA levels in plasma, as suggested by Landman et al. (1984). The significant decrease in the number of lymphocytes at transport may, conversely, solely be an effect of the increased plasma levels of cortisol (Fauci 1979). The large number of PMN cells on the day before transportation is interpreted as an effect of the operation $2 \mathrm{~d}$ before transport (Dalin et al. unpublished).

The cell-mediated immunity, as measured by the lymphocyte proliferation test, did not seem to be affected by the transport stress. On the contrary, blood mononuclear cells from pigs exposed to $30 \mathrm{~min}$ restrain stress were suppressed in their proliferative response to mitogen Con A (Klemcke et al 1990). However, this type of stress caused very high plasma levels of cortisol, almost 3 times higher than in the present study, which may, in turn, explain the difference in results between the studies. Injection of adrenaline in humans causes a highly transient suppression of the proliferative response to Concanvalin A (Crary et al. 1983). Unfortunately, no data about the actual plasma concentrations of adrenaline were obtained in that study. Even so, the absence of effect on the proliferative response by the relatively transient stress in the present study is in accordance with the proposition by Cohen (1987) that mild acute stress does not exert a significant effect on the immunocompetence.

\section{Conclusion}

To conclude, both the plasma levels of adrenaline and cortisol increased significantly during mild transport stress, whereas the noradrenaline value did not change constantly. This may indicate simultaneous activity of both the adrenal cortex and the adrenal medulla. The corticosteroid-binding globulin level changed gradually after transport. The transport stress seemed to affect the number of circulating polymorpho- nuclear neutrophils and lymphocytes, but not cellmediated immunity.

\section{Acknowledgement}

The study was supported by grants from the Swedish Council for Forestry and Agricultural Research and the Swedish Medical Research Council (project no. 166).

\section{References}

Barb CR, Kraeling RR, Rampacek GB, Fonda ES, Kiser TE: Inhibition of ovulation and LH secretion in the gilt after treatment with ACTH and hydrocortisone. J. Reprod. Fertil. 1982, 64, 85 - 92.

Burden HW: The adrenergic innervation of mammalian ovaries. In: Ben Jonathan N, Bahr JM, Weiner RI (Eds.). Catecholamines as Hormone Regulators. Raven Press, New York, 1985, 261 - 278.

Becker BA, Ford JJ, Christensen RK, Manak RC, Hahn GL, DeShazer JA: Cortisol response of gilts in tehter stalls. J. Anim. Sci. 1985a, 60, 264 - 270.

Becker BA, Nienaber JA, DeShazer JA, Hahn GL: Effect of transportation on cortisol concentrations and on the circadian rhythm of cortisol in gilts. Amer. J. vet. Res. 1985b, 46, 1457 - 1459.

Cohen BB: Methodological issues in behavioral immunology. Immunol. Today. 1987, 8, 33 - 34.

Crary B, Borysenko M, Sutherland DC, Kutz I, Borysenko JZ, Benson $H$ : Decrease in mitogen responsiveness of mononuclear cells from peripheral blood after epinephrine administration in humans. J. Immunol. 1983, 130, 694 - 697.

Dalin AM, Nyberg L, Eliasson L: The effect of transportation/relocation on cortisol, CBG and induction of puberty in gilts with delayed puberty. Acta vet. scand. 1988, 29, 207 - 218.

Dalin AM, Magnusson U, Häggendal J, Nyberg L: The effect of pentothal-sodium anaestheisa/operation, relocation, grouping and hydrocortison treatment on the blood levels of cortisol, CBG and catecholamines in pigs. 1992, submitted.

Du Mesnil du Buisson F, Signoret JP: Influences de factuers externes sur le déclenchement de la puberté chez la trui. (The effect of external factors on puberty in gilts). Annu. Zootech. 1962, 11, 53 - 59.

Fauci AS: Immunosuppressive and antiinflammatory effects of glucocorticoids. Monograph. Endocrin. $1979,12,449$ - 465.

Hallman H, Farnebo LO, Hamberger B, Jonsson G: A sensitive method for the determination of plasma catecholamines using liquid chromatography 
with electro-chemical detection. Life Sci. 1978, 23, 1049 - 1052.

Henry JP, Stephens PM: Stress, health and social environment. A sociobiologic approach to medicine. Topics in environmental physiology and medicine. Springer-Verlag, Berlin 1977.

Hoerlein AB: Shipping fever. In: Amstutz HE (Ed.): Bovine Medicine and Surgery, Amer. vet. med. Assoc. 1980, 99 - 106.

Hjemdahl P, Åkerstedt T, Pollare T, Gillberg M: Influence of $B$-adrenoceptor blockade by metoprolol and propanolol on plasma concentrations and effects of noradrenaline and adrenaline during i.v. infusion. Acta Physiol. Scand. Suppl. 1983, 515, 45 - 53.

Hjemdahl P, Freyschuss $U$, Juhlin-Dannfeldt A, Linde $B$ : Differentiated sympatetic activation during mental stress evoked by the Stroop test. Acta Physiol. Scand. Suppl. 1984. 527, 25 - 29.

Häggendal J, Jönsson L, Johansson G, Bjurström S, Carlsten J: Disordered catecholamine release in pigs susceptible to malignant hyperthermia. Pharmacol. \& Toxicol. 1988, 63, 257 - 261.

Johansson $G$, Olsson K, Häggendal J, Jönsson L, Thorén-Tolling K: Effects of stress on myocardial cells and blood levels of catecholamines in normal and amygdalectomized pigs. Can. J. comp. Med. 1982, 46, 176 - 182.

Karlbom I, Einarsson S, Edqvist LE: Clinical appearence and patterns of progesterone, oestradiol$17 ß$ and LH. Anim. Reprod. Sci. 1982, 4, 301 - 312.

Keller R, Oke A, Mefford I, Adams RN: Liquid chromatographic analysis of catecholamines routine assay for regional brain mapping. Life Sci. 1976, 19, 995 $-1004$.

Klemcke $H G$, Blecha F, Nienaber J A: Pituitaryadrenocortical and lymphocyte response to bromocriptine-induced hypoprolactinemia, adrenocorticotroptic hormone and restraint in swine. Proc. Soc. Exp. Biol. Med., 1990, 195, 100 - 108.

Lambooy E: Road transport of pigs over a long distance. Some aspects of behaviour, temperature and humidity during transport and some effects of the last two factors. Anim. Prod. 1988, 46, 257 - 263.

Landmann RMA, Miller FB, Perini CH, Wesp M, Erne P, Bühler FR: Changes of immunoregulatory cells induced by phychological and physical stress: relation to plasma catecholamines. Clin. Exp. Immunol. 1984, 58, 127 - 135.

Magnusson U, Dalin AM: Diurnal changes in the leu- kogram of ovariectomized gilts. Acta vet. scand. 1992, 33, $189-190$.

Magnusson $U$, Fossum $C$ : Variations in number and functional capacity of blood mononuclear cells during the peripartal period in the gilt. J. vet. Med. B. 1988, 35,570 - 578.

Nyberg L, Lundström K, Edfors-Lilja I, Rundgren $M$ : Effects of transport stress on concentrations of cortisol, corticosteroid-binding globulin and glucocorticoid receptors in pigs with different halothane genotypes. J. Anim. Sci. 1988, 66, 1201 . 1211.

Paredis F: Onderzoekingen over vruchtbaarheid en kunstmatige inseminatie bij het varken. (A study of the reproduction and artificial insemination in the gilt). 1961, Phd Thesis, Gent.

Rodriguez $H$, Kunavongkrit $A$ : Chronical venous catheterization frequent blood sampling in unrestrained pigs. Acta vet. scand. 1983, 24, 318 - 320.

Rojasnasthien S: Effect of transportation and relocation in postweaning anoestrous primiparous sows. Acta vet. scand. 1989, 30, 1 - 8 .

Schilling E, von Rechenberg W: Funktion der Niebennierenrinde und Ovulationsprozess beim Schwein (The function of the adrenal and the ovulation process in the pig). Zbl. Vet. A. 1973, 20, $705-717$.

Siiteri PK, Murai JT, Hammond GL, Nisker JA, Raymoure WJ, Kuhn RW: The serum transport of steroid hormones. Recent Prog. Horm. Res. 38, 457 $-510$.

Spencer GSG, Wilkins LJ, Hallet KG: Hormone and metabolic changes in the blood of pigs following loading and during transport and their possible relationship with subsequent meat quality. In: Proc. Symp. 30th European Meeting of Meat Res. Workers, Bristol 1984, 15 - 16.

Spicer LJ: Minireview. Catecholaminergic regulation of ovarian function in mammals: Current concept. Life Sci. 1986, 39, 1701 - 1711.

Åkerstedt T, Gillberg M, Hjemdahl P, Sigurdson K, Gustavsson I, Daleskog M, Pollare T: Comparison of urinary and plasma catecholamine responses to mental stress. Acta Physiol. Scand. 1983, 117, 19 - 26.

\section{Sammanfattning}

Effekten av transportstress på plasmanivåerna av katecholaminer, kortisol, kortisol-bindande globulin, den vita blodbilden och lymfocyt-proliferation hos svin. 
Effekterna av tranportstress på plasma nivåerna av katecholaminer, kortisol och korticosteroid-bindande globulin (CBG) studerades hos 6 gyltor av korsningsras. För att fastställa stressens effekt på immunstatus, räknades de vita blodkropparna och den cell-förmedlade immuniteten bedömdes. Adrenalinnivån ökade signifikant under transporten, från en basnivå på 0.03 $\mathrm{ng} / \mathrm{ml}$ till en platå på $0.11-0.12 \mathrm{ng} / \mathrm{ml}$. Noradrenalinet fluktuerade under transporten. Plasma nivån av kortisol var före pålastningen ca $40 \mathrm{nmol} / 1$ och steg omedelbart efter transportens inledning till $70 \mathrm{nmol} / \mathrm{l}(\mathrm{p}<$ $0.05)$ och $87 \mathrm{nmol} / \mathrm{l}(\mathrm{p}<0.01) 10$ och 30 min därefter. Efter avlastningen minskade kortisolnivån snabbt till lägsta nivå 4 tim efter transporten. Därefter återkom dygnsrytmen. Bindningskapaciteten hos det korticosteroid-bindande globulinet (CBG) ökade (ej sign.) under transportdagen, från $25 \mathrm{nmol} / 1$ till $34 \mathrm{nmol} / 1$, och den fortsatte att öka tills en platå uppnåddes på andra dagen efter transporten. Totalantalet vita blodkroppar ökade signifikant (från 13.7 till $15.5 \times 10^{9}$ celler/l), antalet lymfocyter minskade signifikant (från 8.4 till $7.0 \times 10^{9}$ celler/l) och antalet polymorfkärniga neutrofiler ökade signifikant (från 4.3 till $7.2 \times 10^{9}$ celler/l) under transporten. Ingen signifikant skillnad kunde ses i proliferationssvaret i blodcellskulturen. De viktigaste resultaten var en samtidig aktivitet i binjurebark och binjuremärg under transport.

(Received October 7, 1992; accepted November 18, 1992)

Reprints may be requested from: A. M. Dalin, Swedish University of Agricutural Sciences, Dept. of Obstetrics and Gynaecology, P.O. Box 7039, S-750 07 Uppsala, Sweden. 